Article

\title{
European Policies for Social Inclusion of Roma: Catch 22?
}

\author{
Elena Marushiakova ${ }^{1,2}$ and Vesselin Popov ${ }^{2}$ \\ ${ }^{1}$ School of History, University of St. Andrews, St. Andrews, Fife, KY16 9AR, UK; E-Mail: emp9@st-andrews.ac.uk \\ ${ }^{2}$ Balkan Ethnology Department, Institute for Ethnology and Folklore Studies with Ethnographic Museum at Bulgarian \\ Academy of Sciences, 1000 Sofia, Bulgaria; E-Mail: studiiromani@geobiz.net
}

Submitted: 7 February 2015| In Revised Form: 26 April 2015 | Accepted: 30 April 2015 |

Published: 29 September 2015

\begin{abstract}
The article analyzes contemporary political discourses with regard to social inclusion of Roma on the basis of comparison with achievements and failures in the previous historical period of the communist rule in Eastern Europe. It argues that since the vast majority of the European Roma had lived in the past and continue living nowadays in the countries of Eastern Europe, no successful policy for their inclusion is possible without taking into account the experiences and outcomes of the actions for Roma integration in the socialist period. The experience from the times of socialism shows that successful policies are possible only in an appropriate socio-political context and only if accomplished within the mainstream approach. Against this background, the article scrutinizes the European Policies for Social Inclusion of Roma, and explains why they present a Catch 22 situation: There is a vicious cycle of problems which need to be solved; the solution requires a special policy for inclusion, however this policy stigmatizes Roma and sets them even more apart from the rest of society. Thus the vicious cycle of problems expands. The main point of the article is to propose an explanation of this failure of democracy and liberalism, which could constitute a useful lesson for the future.
\end{abstract}

\section{Keywords}

assimilation; European policy; Gypsies; inclusion; marginalization; Roma; socialism

\section{Issue}

This article is part of the special issue "Talking about Roma: Implications for Social Inclusion", edited by Dr. Eben Friedman (Independent Consultant and Senior Non-resident Research Associate, European Centre for Minority Issues, Germany).

(C) 2015 by the authors; licensee Cogitatio (Lisbon, Portugal). This article is licensed under a Creative Commons Attribution 4.0 International License (CC BY).

\section{Introduction}

In recent years the "Roma issue" is increasingly attracting attention in the public space of united Europe and accordingly, the policies targeting Roma have become a serious challenge at national and European levels. A growing number of Roma activists, scholars, experts, journalists, and recently also some politicians, speak more or less openly about the failure of the European Roma policy. This failure has become already a public secret, although the policy makers consider it inconvenient and embarrassing to acknowledge it. At the same time, however, there is almost no study devoted to the state of the contemporary situation of Roma communities in Europe, which does not point to the deterioration of their economic and social situation in the last over 20 years of transition to democracy and market economy as well as to the increase of interethnic distances, prejudices, hidden discrimination, hatred and open hostility against Roma.

Recently, several very interesting and inspiring analyses of the policies in the last more than 20 years have sought an explanation why the good intentions actually paved the road to hell. None of these analyses, however, has made a connection with the past experiences of policies for Roma inclusion in the region where the majority of Roma live or used to live. With this we do not want to assert that policies towards Roma during the so-called "socialist era" in Eastern Europe were not subject of academic interest till now. On 
the contrary, there are authors, who paid attention not only to policies for Roma inclusion and the situation of Roma in the past, but also in connection with the present (to mention but a few: Bancroft, 2005; Guy, 2001; Klímová-Alexander, 2005; Lemon, 2000; Simhandl, 2006, pp. 97-115; van Baar, 2011; Vermeersch, 2006). Attempts have been done also for an analysis of the social, economic, and political dimensions of Gypsy marginality in different regime types (Barany, 2002). The vast majority of these analyses, however, are embedded in the discourse of the "Cold War" and their main line is to compare and contrast "the past" and "the present" (after the changes from 1989 to 1990) in Central, Southeast and Eastern Europe. What is really missing so far is a disclosure of the continuity of Roma policies in the two periods and their impact on Roma. We firmly believe that it is impossible to make an analysis of contemporary European Roma policies without taking into account the experiences from the previous historical period of the communist rule in Eastern European countries, which had a decisive impact on the life and fate of Roma in the region. Only through linking and crosschecking the past with the present, can the achievements and failures of contemporary policies be explained, and why not also a reasonable prediction formulated about their results.

\section{The Time of Socialism}

The socialist period started with the October Revolution in 1917 in Russia which brought the communists in power and was followed by the formation of the Union of Soviet Socialist Republics (USSR) was constituted in 1922. The USSR became the first and at that time the only country in Europe that realized policies on state level aimed at Gypsy inclusion ${ }^{1}$. It was constituted as a complex structure of national and ethnic state administrative formations at various levels-Soviet republics, autonomous republics and regions. At the same time a considerable number of peoples within the Union were not granted the right to establish their state or administrative units, but only pro-communist socio-political and cultural organizations. Gypsies were among them. This was justified by their small number (considering the scale of the USSR), their largely nomadic way of life, absence of compact territory and of an elite, seeking positions in state and administrative institutions.

The first aim of the new socialist state in regard of Gypsies was their "inclusion into labor for the benefit of society" and their transformation into "conscientious Soviet citizens". To achieve this aim, in the first period of the Soviet state, and in the spirit of the new

\footnotetext{
${ }^{1}$ For sake of historical correctness in this part of our article we are using the term "Gypsies", which is the English translation of local terms, used in historical sources and documents until the end of the twentieth century.
}

national policy, a number of measures were taken such as establishing of Gypsy organizations, providing land, financial support, premises, working equipment, bank credits and cash subsidies for Gypsy kolhozes (cooperative farms) and artel's (co-operative artisan's workshops), alphabetizing the Romani language, publishing textbooks and brochures in Romani, opening Roma schools and classes, creation of Gypsy Theatre Romen in Moscow and numerous musical ensembles countrywide (Crowe, 1996, pp. 182-186; Demeter, Besssonov, \& Kutenkov, 2000, pp. 204-207; O'Keeffe, 2013; Rom-Lebedev, 1990).

A radical change in the Soviet national policy from the so-called "Leninist" to the "Stalinist" national policy began with the new Constitution of the USSR adopted in 1936 and it affected also the Gypsies. The first signs of this policy change were felt already in the early 30 s. The schools of 16 separate nationalities were closed down, including Gypsy schools; mass publication of texts in Romani ceased; and the Gypsy artel's and kolkhozes broke up (Marushiakova \& Popov, 2008a, p. 8).

This was a considerable turn in the policy for Gypsy inclusion in the Soviet state. Until 1938, the policy was based on their treatment as a separate people, who should develop above all as an ethnic community first, and as such it would be included into the Soviet society. After 1938, the paradigm changed, the special element in the policy gave way to the mainstream one, and the Gypsies started to be considered an integral part of the Soviet society, without any special attention. As a community their development was supported only in an ethno-cultural plan (mostly music and dance).

The end of the Second World War and the post-War years were a time of radical change for the countries of Eastern Europe. A new type of state-political system was established, which according to its own phraseology was defined as a "socialist system". Overall social and economic changes were carried out and Roma, in various degrees and in different periods, became target of an active state policy. When the so-called socialist camp is mentioned, frequently the impression is that it refers to a monolithic totalitarian system, directly under the Moscow rule, where a common policy dominated in all spheres. To a certain extent this was the case, yet quite a lot of differences and specific features in the individual countries remained, especially in the field of internal national policy. The common ideology presupposed total unity on the ideological level, and thus each country declared its national policy based on the principles of Marxism-Leninism and Proletarian Internationalism. Each country, however, interpreted these principles in its own way and respectively conducted its own national policy (Marushiakova \& Popov, 2008b, p. 2).

The common ideological framework dictated elimination of the nomadic way of life (defined as vagrant, parasite), poverty and illiteracy; these phenomena 
were declared to be part of the capitalist heritage that should be abolished. The final result from these policies was similar in most of the socialist countries - till the end of the 1960s and 1970s the most severe problems were solved: the nomadic Gypsies were settled, illiteracy was eliminated, the alarming health status was improved, and the most catastrophic housing conditions (dugouts and makeshift dwellings) were ameliorated. The next steps involved civic and social integration of the Gypsies, with four major fields of action identified across the region: housing (dispersal of hamlets and compact settlements, resettlement and decent housing among the majority population), full employment (in the socialist countries employment was obligatory) health and education.

In general, two approaches were applied for the realization of these tasks: the "mainstream one" and the "special one" (sporadically, a mixture of both approaches was also applied). The "mainstream approach" meant that the state did not apply special measures for the social integration of the Gypsies. Their problems were resolved within the framework of the existing mainstream policies targeting the whole population, including the Gypsies (which, however, did not exclude efforts of the authorities to prevent possible deviations from the mainstream way of life). The "special approach" was directed towards the Gypsies as a community with specific problems, which required specific measures for their resolution (e.g. special school or housing programs).

The first approach was typical primarily for the Soviet Union, Yugoslavia, Poland, East Germany (formally the German Democratic Republic), Albania and Yugoslavia where there were no special government programs for Gypsies (with the exception of the program for sedentarization of itinerants in the USSR and Poland). The only sphere of public life in these countries, in which the mainstream policy was not applied, was the preservation and development of Gypsies' ethnocultural identity (e.g. Romen Theatre in the USSR).

In the remaining four countries Czechoslovakia, Hungary, Romania and Bulgaria, i.e. in the countries where the Roma population is most numerous, a "special approach" in the state policy for Gypsy integration was applied, however without abandoning the "mainstream approach". In order not to turn the special measures into exclusive ones, they were kept hidden and in some countries (e.g. Bulgaria and Romania), at one point of time, it was even explicitly forbidden to mention the mere existence of Roma (Achim, 1998, pp. 160-162; Crowe, 1996, pp. 223-225; Jurová, 1993, pp. 27-29; Kovats, 2001, pp. 338-340; Marushiakova \& Popov, 1997, pp. 37-39, 2007, pp. 148-149). It was exactly in the spheres in which the "special approach" was applied that the major failures in the policy of integration occurred. For example, in field of housing, in Slovakia and Hungary the focus was on the elimination of the so-called osady or kolonia (segregated hamlets in the countryside), in Bulgaria policy aimed at the dispersion of urban mahallas (detached ethnic quarters in urban locations). As a result, in Slovakia and Bulgaria appeared segregated blocks of flats which were quickly devastated. In Hungary and Slovakia, the Gypsies were often accommodated in historical houses in town and city centers, assessed as the third lowest category of housing, and as an outcome in the middle of many cities appeared ghetto-like settlements. In the field of education Czechoslovakia introduced the practice of separation of children from their families and forcible placement of Roma kids in boarding schools; in Yugoslavia and Czechoslovakia many healthy children were enrolled in special schools for children with mental disabilities. In some cases fields of action matched, for e.g., in order to solve housing and occupation problems the state send Slovak Roma to Czech industrial regions; in Bulgaria in order to increase Gypsy education level and employment the state introduced vocational, defacto segregated schools, etc. In search of radical solution of the problems authorities resorted to some drastic measures. The most known is the case in Czechoslovakia, in which with the goal of increasing the share of healthy population among the Gypsies, the Ministry of Health, inspired by the so-called Swedish model of integration policy toward Gypsies, in place until 1984 (Svenska Regeringskansliet, 2014), issued in 1972 a Decree for financial encouragement of voluntary sterilization of women, who had given birth to more than four mentally retarded children.

We can summarize that state policies, regardless of the aims set, eventually achieved contradictory results. On the one hand, the living conditions, health and education of Roma have seen a rapid improvement in comparison with the past, the degree of their integration has grown, and even strata of well-educated Roma emerged, etc. On the other hand however, the price paid for this integration was quite high. Many Roma in the countries from the "socialist camp" took on the road of social degradation and marginalization. It is indicative that these processes are best expressed and felt most strongly in countries with clearly formulated specific policies towards Roma and to a much lesser extent in countries where such policies were limited or simply absent.

In the end, it turns out that the social integration of Roma in the countries of the "socialist camp" was determined above all by the overall social development and by the mainstream (general for all citizens) policy towards Roma, and not by the special (targeted on Roma) policies towards them.

\section{Present Time}

More than 20 years after the "wind of change", the European policy makers, intergovernmental organizations active in Europe, individual governments, and civil society actors are searching for tools to solve the numer- 
ous problems, facing Roma communities in the times of transition from Communism to democracy. The documents on Roma published by these actors in the 1990s accused the former communist policy for the precarious situation of Roma (similarly to the communists who blamed the capitalist past) and tended to emphasize human rights policy, which should provide redress for past violations and protection from future discrimination as a basis for calls for measures to improve the Roma's situation (Friedman, 2014, pp. 3, 15). Since then, and until now, in an effort to create a common European policy towards Roma, numerous diverse and often conflicting initiatives and measures were introduced not only in the field of human rights, but also in other areas (see below). European institutions adopted two main initiatives targeting Roma, the Decade of Roma Inclusion (2005), which was initially introduced by the network of the Open Society Foundations, and the EU Framework for National Roma Integration Strategies (2011), followed by the adoption of new (or updating of old) National Strategies all over Europe.

The four priority areas in the European Roma inclusion policy are identified: employment, housing, education, and healthcare (sic! the same as in the communist period, and for the countries of Central Europe, largely the same as the priorities in the state policy of the Austro-Hungarian Empire during the reign of Maria Theresa and Franz Joseph II), with the addition of gender issues and the fight against discrimination and antiGypsyism. Within these areas a number of initiatives started, became a hit for a while, enjoyed active lobbying, advertising and funding for several years, then there was criticism by scholars and civil society actors, and these initiatives usually quietly ceased to be supported and went into oblivion. In the end, we are confronted with a situation in which "we need to acknowledge that most of the money spent by the previous Commission and EU funds spent by Member States were wasted" (Nicolae, 2014). A similar pattern is observed in the activities of private donors and foundations and especially in the activities of the most prominent among them, the network of the Open Society Foundations.

The reasons behind the problems and measures for improvement of the situation are continuously sought at different levels. For a long time the reason of fiascos was seen mainly in the corruption or failure of the various stakeholders, and the solution was sought in endless writing of recommendations, monitorings, evaluations. When this did not lead to success, the search for errors focused on the methods of monitoring or evaluations and began an endless writing of analyses, not of the situation, but of the monitorings and the evaluations. One of the causes for the failures defined is the lack of involvement of the Roma and remedy is sought in increasing of Roma participation at all levels in deci- sion-making and implementation. Responsibility for decisions and for subsequent failures is sought at different levels -it is transferred from nation-state to supranational units and back, from nation state to the civil sector; from the civil sector to the lack of political will of the major political actors. The solution is sought in attempts to change public opinion and to create political will for implementation of measures to improve the Roma's situation.

In addition to all this, currently we have seen the trend to seek the cause of failures and justification for funds invested in vain, in the community itself and its specific culture. The solution-as absurd as it soundsis urging the Roma to change themselves. This trend became prominent at different levels; even the European Commissioner for Justice and Fundamental Rights, Viviane Reding, said in an interview for Euronews on January 16,2014 , that Roma communities need "to be willing to integrate and to be willing to have a normal life", and so the "Roma integration in Europe has shifted to a right-wing definition of integration where the onus is being placed on the minorities to make the adjustments and accommodations deemed necessary for social cohesion" (Rorke, 2014).

Now we have the following situation: a defined problem - the precarious condition of the Roma population, and various proposals for solution made by different stakeholders. This is followed by a lack of success and various excuses why the European Roma policies do not lead to the desired results. Only recently appeared articles which look "at some factors that appear to be key impediments to the development of a sustainable and successful policy" within the European Roma policy making (Popova, 2015).

The starting point is connected with the ideological background. As the Eastern European socialist system was defeated one and the Western democracy won the historical race the recipe for the solution of the Roma issues was initially sought within the experiences of the leading Western democratic countries in which the Roma population is small, with a very short history of inclusion. The Gypsy nomadic way of life, which has disappeared in the East, is considered an immanent ethnic and cultural trait in the West, which should be preserved. This is done even at expenses of their citizens' rights (e.g. in France only now, in June 2015, arrangements are made for cancelling special travel permits that worked as identity cards for Gypsies and Travelers, called "livret de circulation" ${ }^{2}$ ). The sedentary way of life, the socialist experiences of inclusion and the large size of the Roma population in Eastern European were not taken in account.

Admittedly, the picture is not so simple as in East-

\footnotetext{
2 See http://www.lemonde.fr/societe/article/2015/06/10/lassemblee-vote-la-suppression-du-livret-de-circulation-pourles-gens-du-voyage_4650732_3224.html
} 
ern Europe too some Roma continued at least partially their semi-nomadic way of life. The West was not monolithic either. In the countries on that side of Iron curtain some Gypsies have been sedentary for centuries too (in Spain, partially Portugal, Greece, Burgenland in Austria, etc.). These populations were not subject to specific policies for the settling of nomads, but at the same time the Roma there were often unable to benefit from the mainstream conditions and policies (e.g. in Spain Gitanos received full civil rights only after the end of Francoism). These nuances, however, does not change the general picture in the two political blocks as well as the fact that the leading paradigm about Gypsies as nomads was dominant at European level until the end of the Cold War (Liégeois, 1987).

We are convinced that the main reason for the failures of the European Roma policy making is the wrong formulation of the problem, neglecting of the lessons from the previous period, in other words, in the positions which were assigned to Roma in the last circa 20 years of transition. Due to lack of space we cannot go in details and will limited ourselves to the major reasons for the failure of the European policies for Roma inclusion that are rooted in the issues we discuss below.

The first major reason for failure is connected with defining the target, or in other words, with defining "Who are the Roma"? The problem here starts with terminology-in the last circa 20 years the politically correct term is considered to be "Roma" which is the self-appellation of a significant part of communities. Most often however, we see a mechanical replacement of the previously used designations with the term "Roma" and the issue of appropriateness or inappropriateness of the politically correct terminology is not on the agenda. The terminology used, however, reflects certain historical and cultural realities. In today's united Europe we are confronted with overlapping different historical realities and created perceptions, and as a result "two separate signified entities are captured by the term 'Gypsies' (or as it is nowadays considered politically correct 'Roma'). In one case, characteristic for Western Europe, the term denotes the social phenomenon of communities of peripatetics or commercial nomads, irrespective of origin and language. In the other case, typical for Eastern Europe, it is a popular English translation for a set of ethnonyms used by those groups whose language is or was a form of Romani" (Matras, 2004, p. 53).

Naturally, the political solutions of the issues related to the situation of nomadic on the one hand, and settled for centuries, complex ethnic communities, on the other, cannot be the same. In spite of this, on the level of policies we are observing hectic attempts to bring together the two types of communities under one umbrella term, and in this way to justify the common policy aims towards them and predetermine common outcomes for all member states. There have been numerous attempts by policy makers in the European Union and the Council of Europe level to solve the terminological issue and to find appropriate terminology and an umbrella definition. It is enough to quote the latest (for the time being!) "official" definitions in order to obtain an idea about the lack of relevance to the objectively existing realities.

The recently adopted European Framework of $\mathrm{Na}$ tional Roma Inclusion Strategies states: "The term 'Roma' is used-similarly to other political documents of the European Parliament and the European Council-as an umbrella term which includes groups of people who have more or less similar cultural characteristics, such as Sinti, Travellers, Kalé, Gens du voyage, etc. whether sedentary or not..." (EU Framework, 2011). This definition is misleading because Roma who live in Central, Eastern and Southeastern Europe share "more or less similar cultural characteristics" with the surrounding majority population much more than with other groups such as Sinti, Travellers, Kalé, Gens du voyage, etc.

Not better, neither more precise is the definition in the Declaration on the Rise of Anti-Gypsyism and Racist Violence against Roma in Europe of the Council of Europe Committee of Ministers, adopted in 2012: "The term 'Roma' used at the Council of Europe refers to Roma, Sinti, Kale and related groups in Europe, including Travellers and the Eastern groups (Dom and Lom), and covers the wide diversity of the groups concerned, including persons who identify themselves as 'Gypsies'" (Declaration, 2012) These definitions illustrate that it is not clear to date at the level of European institutions "who the Roma are" and thus the approach towards them remains mostly within the framework of centuries-old stereotypes. Actually, we can see the substitution and replacement of the old English term "Gypsies" which denotes nomadic lifestyle with the term "Roma". This is also a kind of continuation of the policies in the period before the 1990's, which reflected the realities of Western Europe and when the documents produced by European and international organizations referred to Gypsies as "travelers", "nomads" or "a population of nomadic origin" (Rövid, 2011 , p. 3). And what is more frightening, in some instances, as for e.g. in regard of Roma migrants from Eastern Europe in Italy and France, the leading political line dictated solutions to their problems is as nomadic communities, which implies the total failure of these policies (Marushiakova \& Popov, 2013a, 2013b).

Nearly all official documents underline the heterogeneity of groups labeled Roma, but in the same time they fail to recognize the importance of such diversity for policies (Rövid, 2011, p. 10). The question of imposing definitions what should be understood under the term "Roma" is connected to the issue of "power and labeling" (Tremlett \& McGarry, 2013, p. 5). In fact, it demonstrates the Pyrrhic victory of the West over the 
East, because a legitimate question that arises is, whether it is possible at all to have a successful realization of national and supranational policies if they are based on strategies and programs, in which it is not clear who is the main target.

In the struggle to find a common cover term and making efforts to have a common, unified European policy, the European institutional documents suggested Evidence-based policy making as most appropriate for building up a pan-European overview of the challenges facing Roma minorities. (Tremlett \& McGarry, 2013, p. 5). The "evidence-based" is connected to the "good practices", thus EU programs and projects envisage exchange of good practices. However, these good practices are extracted from the nowadays practice, while failures and successes in the past are not taken into account, neither are the differences across the regions and the heterogeneity of Roma communities.

The question whether it is really possible at all to have a common strategy, or even just a general framework for the various national strategies towards communities that differ so much in their origin, ways and conditions of life, languages, cultures, etc., which are not only internally heterogeneous, but also socially and culturally differentiated and diverse and which are united only by an umbrella term, remains unanswered on the political level. Maybe surprisingly an answer comes from some Roma activists from former Yugoslavia who demanded introduction of two European Roma strategies-one for the Roma from the Balkans and another one for all nomadic communities from Western Europe. In this line of thinking is also the insistence of other Roma activists from the Balkans for a change in the overall approach towards the Roma issues - on the one hand, to address the problems of Roma as a vulnerable group together with problems of all vulnerable people, without mixing them with Roma issues, and on the other hand to formulate as Roma issues only the issues pertaining to the preservation and development of Roma language and culture, which would lead to strengthening of the Roma identity.

The second, no less important issue is to clarify the contents of the target, or in other words, in what discourse are considered Roma when key policies towards them are designed and implemented. The European Roma policies display a misunderstanding of the specific character of existence of Roma communities in the region in question. The Roma communities are not a hermetically isolated and self-sufficient social and cultural system; they have always existed here in the inseparable unity of at least "two dimensions" - both as a separate ethnic community and as an ethnicallybased integral part of the society within the respective nation-state in which they have lived for generations, and of which they are full-fledged citizens (at least de jure) (Marushiakova \& Popov, 2011, p. 54).

The failure to comprehend the essence of the "community-society" distinction, interconnection and unity, results in the framing of the Roma communities within two basic paradigms, which can be summed up as marginalization-as a social layer of the society, and exoticization-as a separate community. In both cases we can speak about two interconnected paradigms, which stream from the prism of orientalism (Marushiakova \& Popov, 2011, p. 61).

When the Roma are seen primarily as part of the respective social structure in the forefront are the problems of their marginalization, which are usually seen in socio-economic terms. A great number of NGOmanaged projects have been implemented to overcome this inequality, later followed by national programs and then also by European Union project lines. The leading concept of this approach is that Roma should not be treated as a "normal community", with its own identity, ethnic culture, but as strongly marginalized and to a great extent anomic community, that needs constant special care and social patronage. In the difficult period of the transition in Eastern Europe, the "Roma issue" and the Roma problems have fast been translated into the concept of the social inequality of the Roma community as such. Most national and supranational documents contain notions as "socially excluded", "marginalized", and "vulnerable" Roma communities, which de-facto equate the notions of Roma and marginalization. In order to avoid misunderstanding we would like to stress that we are in no way trying to state that the majority of Roma communities do not face major social and economic problems. However, the key problem lies elsewhere-in the real and present danger that the whole will be confused with its part, i.e. the entire ethnic community will be viewed and identified only with its problematic section and as a result, Roma will no longer be considered and accepted as a distinct ethnic community with its specific ethnic culture. Thus the logical result is to look for solutions of the problems through assimilation.

In parallel to the main social paradigm of marginalization, there is another one, which at first glance is an antipode of the previous. When the Roma are primarily seen as a detached ethnic community, and when the general cultural context and its social dimensions are ignored, it appears that their exoticization has been logically reached. According to this paradigm, which is very popular in Western Europe, the Roma are a community that is characterized by its uniqueness and peculiarity (in terms of way of life and culture); they should not be perceived and treated as a community of the same rank as all other ethnic communities, but a very special approach towards them is needed. Transferring this exoticizing paradigm into the sphere of social policy leads to the outcome that the Roma are not perceived and treated as a community of the same rank as all other ethnic communities, but a very special approach towards them is needed, which will take into 
account and will preserve and further develop the extremely specific Roma ethnic culture.

These two paradigms of practice often go hand in hand, and they are indeed the two sides of the same coin. Currently in numerous programs and projects we can observe some kind of a schizophrenic model, combining the approaches toward Roma as an exotic community and in the same time as a marginal part of the majority society. Paradoxical as it may sound, it is not uncommon that both approaches which at first glance look totally opposing to each other can in fact be combined, and can actually complement each other, in particular when discussing specific policies, programs and projects of governmental and public structures, and/or civil society organizations on various levels. The most outspoken example here is from field of education - all EU strategic documents proclaim as main principle the desegregation of the Roma schools, i.e. mainstream education for Roma, as the main principle, and at the same time numerous EU projects are supporting Roma teacher assistants, school mediators, etc., i.e. various forms of special schooling for Roma (Russinov, 2013, pp. 415-432).

The third major problem is in the discourse of Roma policies (mainstream or specific), or in other words, whether they should be part of the mainstream policies (European, national, regional, local) or special policies targeting solely Roma. This problem arises directly from the previous one because whether Roma are treated as an exotic or marginalized community, or as a kind of combination of the two, the conclusion is the same-the need for specific policies towards them.

In the period of pre-accession to the European Union, the countries of Central and Eastern Europe had to elaborate and implement National strategies or programs for solving the Roma issues as condition to meet the criteria for EU membership. Under pressure from the West (and in the majority of cases with financing and expert assistance from the West) such strategies and programs were prepared and although they were specific for the individual countries, all of them were entirely in the discourse of special policy towards Roma (Guy, 2001).

The situation changed dramatically after the accession of the majority of the countries in Central and Eastern Europe to the European Union and the removal of visa restrictions. The mass migration of Roma from the new member states and incapability of Western Europe to deal with it (particularly acute in Italy and France, but to a lesser extent in other Western countries too) have clearly shown that special policies towards the Western "Gypsies", "Gens du voyage", "Zingari", transferred to Eastern European Roma (e.g. the treatment of "Rom, Sinti et Camminanti" in Italy) not only do not help the integration of Roma migrants but on the contrary, these policies discredit their public image (van Baar, 2015) and lead to marginalization and de-socialization of significant parts of these migrants. (Marushiakova \& Popov, 2013a, 2013b)

One of the unanticipated outcomes of the special policies is the rise of xenophobic and racist discourses towards Roma, due to the fact that the European Roma policies are interpreted by the local populations in individual countries as special privileges for the Roma (Vermeersch, 2012, p. 1209). Special policies implemented in fact are leading to further stigmatization of Roma and as such they not only do not solve problems, but rather expand and deepen them.

In spite of this, the special approach remains enshrined in the EU Framework for National Roma Integration Strategies too, according to which the "national, regional and local integration policies focus on Roma in a clear and specific way, and address the needs of Roma with explicit measures to prevent and compensate for disadvantages they face" (An EU Framework, 2011). The stress on special policies remains also in the promotion of "explicit, but not exclusive targeting" (Vademecum, 2011) as one of the Common Basic Principles on Roma Inclusion, because the explicit focus on Roma inevitably is also exclusive. Explicit focus on Roma leads to their separation from all other communities, which are not focused explicitly. At the same time bridging this separation is envisaged through the principle of mediation to which a special joint initiative of the Council of Europe and the European Commission is devoted, called ROMED (started in 2011). The principle of mediation is applied exclusively to Roma, but not to any other ethnic minority in Eastern Europe. Specially trained Roma are assigned to the role of mediators with Roma communities in the fields of employment, healthcare services, education and others, thus again they are set apart from everybody else.

Moreover, even programs that conceptually are not focused on Roma, are interpreted as "programs for Roma". The most striking example in this regard is in the field of social housing policy in which ethnicity is only one out of several criteria for distributing apartments in apartment buildings and so apparently, it should not be exclusive in theory. The facts, however, show another reality: For example, in the Czech Republic social housing policy has already led to the creation of new Roma ghettos. General programs for the construction of social housing in Bulgaria are publicly presented by politicians and the media as building "housing for Roma", a discourse that only amplifies antiGypsy attitudes in society, and as a result these programs are stigmatizing and segregating. Even the notorious case of Pata Rat in Romania presents a kind of social housing policy: modular social houses near the city's garbage dump provided to evicted Roma.

\section{Discussion}

Assessment of state policies towards Roma during the 
so-called "socialist period" remains to date in the discourse of the "Cold War". The policy as a whole as well as its concrete manifestations are seen as one of the numerous crimes of a totalitarian regimes. The denial of Roma's ethnic identity, the push towards assimilation, and the assignment of Roma to a lower social status are considered to be the main sins of the former regimes. It is difficult today, seen from the point of view of ideological clichés, to find an objective and comprehensive analysis of these state policies in their complexity. The main problem here is to arrive at a distinction of and establish the relations between two interrelated and frequently overlapping processes-the process of social inclusion and ethnic assimilation. In the course of history many peoples, that lived surrounded by alien nations, went on the way from social integration to assimilation (as a natural process or as the outcome of a certain state policy). Following the logic of this model, (which by no means is universal) and applying it towards Roma, each state measure in the "socialist camp" directed towards Roma integration could be condemned as a step aiming at assimilation.

An objective analysis of state policy towards Gypsies requires a specific approach, in line with the particular situation in each country. Many circumstances should be taken into account, among them the place of Roma in the general context of national state policy in the respective country, and thereby the ratio between mainstream and special policy towards them. The last clarification is necessary, as Gypsies have never been the main target of a national policy in any of the socialist countries (unlike other minority groups), they have always been seen as a less significant group. Attitudes towards them have been contingent on the general strategic aims of the national state policy, defined according to the situation in a given country.

Having in mind the situation of Roma prior to the "socialist era" and after it, it is evident that the outcome of the policies towards Roma in the countries of the socialist camp was achieved above all due to the overall social development and the mainstream policy towards Roma (the general policy applying to all citizens, including Roma),, and to a much lesser extent due to the special policies towards Roma. The special policies were the main source of predicaments experienced by Roma during the times of the communist rule.

The socialist period ended by 1989 giving way to the much desired democracy. Roma from all over the former socialist countries now struggle again with inhuman housing conditions, unemployment, bad health status, problems with education, growing illiteracy, and other social ills. In many instances their present situation is reminiscent of the times before socialism.

Usually the "New Time" is opposed to the previous era, or in other words "the Time of Democracy" is opposed to the so-called "Time of Communism", but in terms of governmental policies aiming at Roma inte- gration there is clear succession and continuity. Indeed, there is a major difference in terms of ideological reasoning and phraseology, but apart from that, in both historical periods the main aim was integration, and the policy agenda for Roma inclusion was and is mainly focused around the same thematic policy areas: housing, health, education and employment. The activities planned and accomplished nowadays, as well as the projects directed to the solution of Roma problems (including the new European strategies, programs and projects) are to a great extent well known from the recent past.

The main difference between the socialist policies for inclusion and the contemporary European policies is the prevalence of mainstream policies in the past and the emphasis on special, targeting, explicit policies nowadays.

Roma policies today are taking place in a complicated socio-political context of a difficult period of transition marked by frustrations in the former socialist countries due to the loss of social stability and security that were guaranteed in the past, due to failed hopes for prosperity and dignity associated with the change of the political system and the entry into the new powerful and rich bloc of the EU. In the European history, in critical socio-economic situations, the role of the main culprit for the failures of society has been ascribed usually to different ethnic minority communities. In conditions of transition, when the new socioeconomic and political system was being established, with numerous difficulties, throughout Eastern Europe, the position "scapegoat" was assigned to them and the Anti-Roma public attitudes in society became widespread.

The prejudices and negative attitudes towards Roma in this region are not new, however, they were largely mitigated in the previous historical period. In the so-called "socialist camp" it was impossible and even unthinkable to demonstrate publicly anti-Gypsy attitudes in any form. The principle of so-called "proletarian internationalism" which was dominant at the official ideological level excluded demonstration of any form of racial and ethnic discrimination towards any community, and racism and discrimination were seen as intrinsic to the "decaying" Western capitalist system. The results, however, should not be overestimated, as the anti-Gypsy attitudes were not removed, they were just not publicly expressed and continued to exist in a latent state (Marushiakova \& Popov, 2013c).

With the change of social conditions in the years of transition in Central and Southeastern Europe in terms of gaining democracy, understood in contrast to the previous totalitarian system as "liberty without borders" these anti-Gypsy attitudes not only received unlimited opportunities for public expression, but were considerably widened and deepened by acquiring new, hitherto unknown dimensions. In contrast to the previous era when the disregard of the main ideological 
norms in public was unthinkable and would lead to an immediate punishment, the non-interference and lack of actions from Brussels to the overt anti-Roma speeches and actions even by representatives of national governments support the conviction that any form of anti-Gypsyism will pass.

Moreover, during the transition years a new antiGypsy stereotype was gradually instilled in the public consciousness. It is that Roma are a privileged group, that undeservedly enjoys privileges not available to the majority. Based on this stereotype Roma began to be perceived as a community, which not only parasitize on the labor of the society, but is also supported to do so. The Roma are perceived as a community, which makes their living mainly from social assistance and child allowances; to whom are devoted many special programs and projects; who receive huge funds that are then abused by Roma "bosses" (whatever that should mean); and who are engaged in widespread criminal activities. The general public firmly believes that the "Gypsies" are allowed not to comply with the national laws, to violate public order and not to fulfill their civic obligations; on the contrary, they are allowed by the state and by Brussels to enjoy special privileges and to be parasites. Direct related to this new public stereotype are apocalyptic pseudo-demographic studies that are being disseminated for years with the active role of the media, which predicts the "Gypsyisation" of the nation, i.e. the extinction of the main ethnicity due to the high birthrate of the Roma, and present Roma as a thread for the existence of the nation-states. In some countries the total disappointment with the entire political class has led to the firm conviction that politicians get elected by purchasing the vote of the Roma. The negative public image of Eastern European countries in the West is explained by the mass migration of Roma criminals and social assistance tourists. In the end, the Roma provide ideal excuses for the "EU's dream deferred" (Sigona \& Trehan, 2011) and for the overall failures of the transition and the European integration.

Political elites in Central and Southeastern Europe often use the misconception of the special, privileged position of Roma as a cover for their own bankrupted efforts to solve the real problems of Roma, justifying their policy for social integration of Roma (or more often an imitation thereof) as a result of pressure from outside (by European Union, USA or numerous international organizations and institutions). The adoption of the European Framework of National Roma Inclusion Strategies (2011), which obliges EU member states to develop their national strategies for solving the problems of Roma, among other things, has strengthened in the public consciousness in Central and Southeastern Europe the stereotype that Roma enjoy a special, privileged position.

By way of summing up the foregoing we can say that the escalating trajectory of the anti-Gypsy atti- tudes and stereotypes in Central and Southeastern Europe over the past two decades suggests perhaps a less expected, even seemingly paradoxical, conclusion that the policies of "explicit, but not exclusive" targeting of Roma, regardless of good intentions, have led and will also lead in the future to results contrary to the expectations, if not implemented with a careful consideration of their overall societal impact.

As a result from the European policies of social inclusion of Roma the misconception of the special privileges for Roma has become the foundation on which the mass anti-Roma attitudes and stereotypes were rethought and developed until they firmly entered the public consciousness and became justification for all failures in the transition period in the new European realities. It is this new stereotype that has feds the numerous overtly nationalistic and pro-nationalistic parties in the whole region of Europe in the last decade and contributed to the strengthening of anti-European attitudes in the region.

It turns out that the more policies, programs and projects aimed at Roma are realized, the more aggravated are the anti-Roma public attitudes. In this situation, all explicit actions are pre-doomed to failure. All said above should not be perceived as an argument against any positive action regarding Roma. It is mandatory, however, before proceeding in the direction of such policies, to analyze very carefully and in all public aspects the results of previously implemented similar policies, starting from the "socialist era", with all its pros and cons, and to consider all possible consequences which they could have (both in with respect to Roma themselves and with respect to the whole society). Special Roma policies and projects, whether at European, national, regional or local levels, must be clearly focused and carefully implemented to avoid all possible negative consequences.

The only sphere of life were the explicit approach appears does not appear to cause any harm is the support of Roma identity in its different dimensions, e.g. language, culture, music, arts, etc. Such policies and projects are particularly necessary for the preservation, maintenance and development of the Romani language and ethnic culture, i.e. they are ultimately needed for the development of the Roma ethnic identity and positive self-esteem. A similar view was recently expressed by an activist, Rom from Bulgaria, in his open letter: "I realize the NRIS [Framework for National Roma Integration Strategies 2012-2020] was created as a sign of the good will and intensions of the European Commission to integrate Roma and try to improve their livelihood. But I don't really feel the need to be integrated or socially included-not that I am an antisocial creature-by anyone. I simply feel the need for my language, culture and history to be recognized and accepted as equal.... hope you will stop calling me marginal in your efforts to help me" (Stoyanov, 2015). 
All in all, the possibility of Roma to receive support for the development of the Roma ethnic culture is the only thing which distinguishes positively today's policies from the previous era, and despite massive anti-Gypsy attitudes in the society policies in this sphere still have a chance to succeed without negative social effects.

\section{Conclusion}

Policies towards Roma in the two historical periodssocialism and post-socialism, display a certain continuity, even though they are built on different ideological bases and therefore are usually considered in opposites. The main issue, however, is not how contemporary policy discourses on Roma relate to the official socialist discourses on Gypsies, because in the end, the two are rather similar. Regardless of the discourses, from human point of view and for Roma themselves, much more important are the results from the policies than their motives and objectives. To answer the question about the comparability of the results of these policies in the two periods is quite a difficult task. Most important is what will be compared. If we compare results within the four main priorities (employment, housing, education, and healthcare) the general picture is ambiguous and in some ways contradictory. In the field of employment, during the socialist period there was full (or nearly full) employment of Roma (as said above, to be unemployed was considered illegal), while nowadays the unemployment rates of Roma are extremely high (in any case much higher than the average unemployment in their respective countries). Similar is the situation in healthcare, where the main indicators in the case of Roma are worse today compared with the preceding period; moreover in some of the former socialist countries (e.g. Bulgaria) large parts of the Roma have entirely dropped out from the healthcare system. In the field of education, during the socialist period, the illiteracy which affected almost the entire Roma population prior to that period, was completely eradicated; nowadays the number of illiterate Roma is increasing again significantly; there is a sharp increase of school dropout rates, and there are children who are excluded from the school system. Along with these negative trends, however, the proportion of Roma with university education increased. In the field of housing the comparison of the two periods also leads to contradictory conclusions: The failure of socialism to complete its programs for the elimination of the separate Roma settlements and neighborhoods is not overcome until today; today many new illegal settlements are arising, the problem of homelessness appeared (to be homeless was also illegal in socialist times); in some cases, however, (as e.g. in Slovakia) at least some conditions in some isolated settlements were improved.

As we analyzed above, in terms of contents, the Roma policies pursued in the "socialist era" were quite similar with the current European Roma policies. The main difference comes from the fact that in the previous period these policies were implemented under the control of the totalitarian state, which excluded the possibility for public disapproval. Thus, at least from today's point of view, the socialist policies look more effective and successful.

The most important (but unfortunately the sole) advantage of the new age is the constitutional and legal instruments that guarantee the fundamental human and minority rights of the Roma and "the satisfaction at the long-awaited recognition of their ethnic identity" (Guy, 2001, p. xv) These guarantees have removed the existent real danger of Roma's forced assimilation and eradication as an ethnic community, ensured their freedom to express publicly their ethnic identity, and opened the possibility of preserving, maintaining and developing their language and ethnic culture. Unfortunately however, as seen from the distance of time, it appears, that "the Roma have been among the biggest losers in the transition from communism since 1989" (Wolfensohn \& Soros, 2003). Moreover, whereas the total denial of everything that the socialist Roma policies achieved for the social integration of the Roma has ultimately led to discouraging results; the immense social disintegration of Roma is strikingly visible in the new social realities across the region. The processes, resulting from the contemporary policies lead to the domination of mass anti-Gypsy attitudes and the latter inevitably affect public policies; these attitudes immediately find their expression in the media and threaten to discard the advantages for the Roma that the "new times" have brought. So we are witnessing once again a growing number of people hiding their Roma identity and aspiring for assimilation in order to escape anti-Gypsy attitudes.

The overall development of the European Roma policies has already created a situation in which no matter what action and no matter which kind of the programs and measures will be implemented, all they will only exacerbate the problems. It appears that we already reached the situation, in which there is no solution and every step could be only a wrong one. In recent years, the Roma themselves have tried to analyze the results of current policies, programs and projects and to search for prospects. Perhaps most impressive was the action of young Roma activists in 2011, who during a meeting on Roma issues with representatives of the European Commission in Bulgaria called for a discontinuation of all European programs and projects for the Roma and raised huge banners with slogan: "Europe, stop funding Roma Exclusion".

A similar request was formulated by the prominent Roma visionary and activist Nicolae Gheorghe, who passed away on 8 August 2013. In his recently published text, a kind of political testament, he said: "projects for Roma, which are financed by structural or re- 
gional development funds, should be stopped for a while. This is in order to have a moratorium and assess what is actually happening with these projects on the ground" (Gheorghe, 2013, p. 47).

Contemporary European Roma inclusion policy reminds the Catch 22. There is vicious cycle of problems which need to be solved; in order to be able do it, a special policy for inclusion needs to be introduced; this policy, however, stigmatizes Roma and sets them even more apart. Realistically spoken, it is obvious that the European Roma policies, programs and projects will continue. The question is what to do in order to stop the steady deterioration of the situation, to avoid repeating the mistakes, and to put an end to the contemporary social engineering for the creation of a united exotic and marginal community defined under the umbrella term Roma. World history offers sufficiently evidence about the consequences of social engineering, constructed on the basis of certain ideologically justified visions; there is no need to re-confirm the aphorism that the only lesson of history is that nobody draws lessons from it, this time at the expense of the Roma. The way out is to break the vicious circle of approaching the Roma as social marginals or as an exotic community, whose successful social inclusion requires special policies towards them, and to address them, as all other citizens of the European Union. Considering the possible solution we would like to quote literally the words of one of our old Roma friend, said circa two decades ago about those who work in the field of Roma policies: "they just need to understand that we are normal people like everyone else, and stop to look at us as aliens". There is nothing more to add to this.

\section{Post Scriptum}

Beyond the scope of this article is left another important issue of past and current policies for social integration of Roma, namely the participation of Roma representatives in them. More precisely said, left out is the issue about transforming the Roma from passive object into an active subject in the processes of social inclusion, (which is however not the same as the slogan often repeated in the last two decades "nothing on Roma without Roma"). This issue is too large to be included here and too important to be only briefly mentioned. It deserves to be elaborated in deep in a separate piece of work.

\section{Acknowledgments}

Our deep gratitude belongs to our numerous Roma friends from across the Eastern Europe, with whom we had endless talks about 'what went wrong and why', which inspired the writing of this article. The Leverhulme Trust Visiting Scholarship is warmly acknowledged, together with collegial intellectual support in the vibrant research environment at the School of History at the University of St Andrews.

\section{Conflict of Interests}

The authors declare no conflict of interests.

\section{References}

Achim, V. (1998). Tiganii in istoria Romaniei. Bucureşti: Editura Enciclopedica.

An EU framework for national Roma integration strategies up to 2020. (2011). European Commission COM. Retrieved from http://ec.europa.eu/justice/ policies/discrimination/docs/com_2011_173_en.pdf

Bancroft, A. (2005). Roma and Gypsy-Travellers in Europe: Modernity, race, space and exclusion. Aldershot: Ashgate.

Barany, Z. (2002). The East European Gypsies: Regime change, marginality and ethnopolitics. Cambridge: Cambridge University Press.

Crowe, D. (1996). A history of the Gypsies of Eastern Europe and Russia. New York: St. Martin's Griffin.

Declaration of the Committee of ministers on the rise of anti-Gypsyism and racist violence against Roma in Europe. (2012). Adopted on 1 February 2012. Retrieved from https://wcd.coe.int/ViewDoc.jsp?id=1 902151\&Site $=$ CM

Demeter, N., Besssonov, N., \& Kutenkov, V. (2000). Istoriya tsygan: Novyi vsglyad. Voronezh: Institut etnologii i antropologii RAN.

Friedman, E. (2014). The situation of Roma between human rights and economics. ECMI Issue Brief, 31, 1-27.

Gheorghe, N. (2013). Choices to be made and prices to be paid: Potential roles and consequences in Roma activism and policy-making. In W. Guy (Ed.), From victimhood to citizenship: The path of Roma integration (pp. 41-100). Budapest: Kossuth Kiadó.

Guy, W. (Ed.) (2001). Between past and future: The Roma of Central and Eastern Europe. Hatfield: University of Hertfordshire Press.

Jurová, A. (1993). Vývoj rómskej problematiky na Slovensku po roku 1945. Košice: Goldpress.

Klímová-Alexander, I. (2005). The Romani voice in world politics: The United Nations and non-state actors. Hants: Ashgate.

Kovats, M. (2001). Hungary: Politics, difference and equality. In W. Guy (Ed.), Between past and future: The Roma of Central and Eastern Europe (pp. 333350). Hatfield: University of Hertfordshire Press.

Lemon, A. (2000). Between two fires: Gypsy performance and Romani memory from Pushkin to postsocialism. London: Duke University Press.

Liégeois, J.-P. (1987). Gypsies and Travellers. Strasbourg: Council for Cultural Cooperation.

Marushiakova, E., \& V. Popov (1997). Gypsies (Roma) in 
Bulgaria. Frankfurt am Main: Peter Lang.

Marushiakova, E., \& V. Popov (2007). Zigeunerpolitik und Zigeunerforschung in Bulgarien (1919-1989). In M. Zimmermann (Ed.), Zwischen Erziehung und Vernichtung. Zigeunerpolitik und Zigeunerforschung im Europa des 20. Jahrhunderts. Beiträge zur Geschichte der Deutschen Forschungsgemeinschaft (Band 3, pp. 125-156). Stuttgart: Franz Steiner.

Marushiakova, E., \& V. Popov (2008a). Soviet Union before World War II. In Information Fact sheets on Roma history. Strasbourg: Council of Europe. Retrieved from http://www.coe.int/t/dg4/education/ roma/histoCulture_en.asp

Marushiakova, E., \& V. Popov (2008b). State policies under communism. In Information fact sheets on Roma history. Strasbourg: Council of Europe. Retrieved from http://www.coe.int/t/dg4/education/ roma/histoCulture_en.asp

Marushiakova, E., \& V. Popov (2011). Between exoticization and marginalization: Current problems of Gypsy studies. Behemoth. A Journal on Civilisation, 1, 51-68.

Marushiakova, E., \& V. Popov (2013a). Roma migrations vs. Gypsy nomadismus. In B. Schrammel-Leber \& B. Tiefenbacher (Eds.), Romani V. Papers from the Annual meeting of the Gypsy Lore Society, Graz 2011 (pp. 113-134). Graz: Grazer Linguistische Monographien.

Marushiakova, E., \& V. Popov (2013b). Two patterns of Roma migrations from Southeastern Europe. In: T. Dimitrova \& T. Kahl (Eds.), Migration from and towards Bulgaria (pp. 227-244). Berlin: Frank and Timme.

Marushiakova, E., \& V. Popov (2013c). Roma identities in Central, Southeastern and Eastern Europe. In $\mathrm{H}$. Kyuchukov \& O. Rawashdeh (Eds.), Roma identity and anti-Gypsyism in Europe (pp. 40-52). München: LINCOM.

Matras, Y. (2004). The role of language in mystifying and de-mystifying Gypsy identity. In N. Saul \& S. Tebbut (Eds.), The role of the Romanies (pp. 53-78). Liverpool: Liverpool University Press.

Nicolae, V. (2014), Between a rock and a hard place: The new Commission and the social inclusion of Roma. Retrieved from http://valeriucnicolae.word press.com/2014/09/24/between-a-rock-and-ahard-place-the-new-commission-and-the-socialinclusion-of-roma

O’Keeffe, B. (2013). New soviet Gypsies: Nationality, performance, and selfhood in the early Soviet Union. Toronto: University of Toronto Press.

Popova, Z. (2015). "Roma” policy making: Key Challenges and possible solutions. ECMI Issue Brief, 34, 1-12.

Rom-Lebedev, I. (1990). Ot tsiganskogo khora k teatru "Romen". Moscow: Sovetskii pisatel.
Rorke, B. (2014). Roma integration and "normal way of living". Open Democracy. Retrieved from https:// www.opendemocracy.net/can-europe-makeit/bernard-rorke/roma-integration-and-normalway-of-living

Rövid, M. (2011). One-size-fits-all-Roma? On the normative dilemmas of the emerging European Roma policy. Romani Studies, 21(2), 1-22.

Russinov, R. (2013). Segregation and the Roma. European Yearbook of Minority Issues (Vol. 10, pp. 415432). Leiden \& Boston: Koninklijke Brill.

Sigona, N., \& Trehan, N. (2011). Neoliberalism, antiGypsyism and the EU's dream deferred. Lignes, n. 34.

Simhandl, K. (2006). Western Gypsies and TravellersEastern Roma: The creation of political objects by the institutions of the European Union. Nations and Nationalism, 12(1), 97-115.

Stoyanov, A. (2015). EU is calling me poor! Retrieved from: https://raklata.wordpress.com/2015/03/22/ eu-is-calling-us-poor

Svenska Regeringskansliet Arbetsmarknadsdepartementet. (2014). Den mörka och okända historien: Vitbok om övergrepp och kränkningar av romer under 1900-talet. Stockholm: Fritze.

Tremlett, A., \& McGarry, A. (2013). Challenges facing researchers on Roma minorities in contemporary Europe: Notes towards a research program. ECMI Working paper, 62, 1-19.

Vademecum. (2011). The 10 common basic principles on Roma inclusion. Retrieved from http:// www.coe.int/t/dg4/youth/Source/Resources/Docu ments/2011_10_Common_Basic_Principles_Roma_ Inclusion.pdf

van Baar, H. (2011). The European Roma: Minority representation, memory, and the limits of transnational governmentality. Amsterdam: F \& N Eigen Beheer.

van Baar, H. (2015). The perpetual mobile machine of forced mobility: Europe's Roma and the institutionalization of rootlessness. In Y. Jansen, J. de Bloois, \& R. Celikates (Eds.), The irregularization of migration in contemporary Europe: Deportation, detention, drowning (pp. 71-86). London \& New York: Rowman \& Littlefield.

Vermeersch, P. (2006). The Romani movement: Minority politics \& ethnic mobilization in contemporary Central Europe. New York \& Oxford: Berhahn Books.

Vermeersch, P. (2012). Reframing the Roma: EU initiatives and the politics of reinterpretation. Journal of Ethnic and Migration Studies, 38(8), 1195-1212.

Wolfensohn, J. D., \& Soros, G. (2003). Why the Roma matter in Europe. Keynote paper at the conference on Roma in an Expanding Europe: Challenges for the Future, Budapest, 30 June-1 July. 


\section{About the Authors}

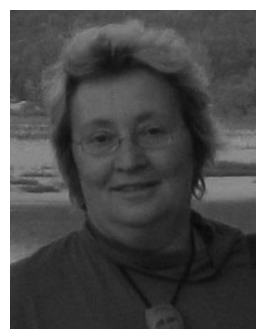

Dr. Elena Marushiakova

Elena Marushiakova is Associate Professor at the Department of Balkan Ethnology at the Institute of Ethnology and Folklore Studies with Ethnographic Museum of the Bulgarian Academy of Sciences. From January 2015 Elena Marushiakova is a Leverhulme Visiting Professor at the University of St. Andrews. She has worked in the field of Romani studies for more than 3 decades and published widely on Roma in Bulgaria, Balkans and Central and Eastern Europe. Her major publications include the first-ever monograph on Roma history and ethnography of the Roma in Bulgaria (1997), on the Roma in the Ottoman Empire (2000); alongside a book on Roma in the Black Sea region (2008). Elena is President of the Gypsy Lore Society, which is the world's oldest organization of Roma studies.

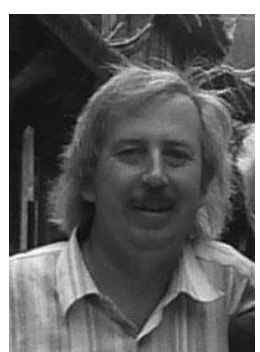

Vesselin Popov

Vesselin Popov is Associate Professor at the Department of Balkan Ethnology at the Institute of Ethnology and Folklore Studies with Ethnographic Museum of the Bulgarian Academy of Sciences. He has worked in the field of Romani studies for more than 3 decades and published widely on Roma in Bulgaria, Balkans and Central and Eastern Europe. His major publications (in co-authorship with Elena Marushiakova) include the first-ever monograph on Roma history and ethnography of the Roma in Bulgaria (1997), on the Roma in the Ottoman Empire (2000); alongside a book on Roma in the Black Sea region (2008). 